\title{
Research on the involvement of residents and tourists in protecting the local brand as a sustainable destination
}

\author{
Mădălina Serban ${ }^{1}$, Maria Magdalena Turek Rahoveanu ${ }^{1}$, Gheorghe Adrian Zugravu ${ }^{1}$ and \\ Cornel Băniță² \\ ${ }^{1}$ IMADR, "Dunărea de Jos" University of Galaţi, 80008, Galați, Romania \\ ${ }^{2}$ UASMV Bucharest, Manager Tehnic SDCDVP PIETROASA ISTRITA, Buzău, Romania
}

\begin{abstract}
.
Research background. Specialists show a decrease in awareness of the issues of sustainability of tourism activities among various stakeholders [1], followed by arguments [2], and irresponsible practices of visitors.

Local key actors could be the main interdependent factors in solving [3] these issues that characterize sustainable tourism through the emergence of the phenomenon of digitalization and high popularization of social networks.

Digital communication networks have left their mark on the impact that brand tourism - considered as local tourist destinations, has on the behavior of residents and tourists [5], [6].

In this research we aim to evaluate the various advantages that sustainable tourism can have due to digital media in the Pietroasele area, Buzau County, Romania.
\end{abstract}

Purpose of the article. In this research we aim to evaluate the various advantages that sustainable tourism can have due to digital media in the Pietroasele area, Buzau County, Romania.

Methods. Digital communication networks have left their mark on the impact that brand tourism - considered as local tourist destinations, has on the behavior of residents and tourists [7],[8],

Findings \& Value added. The aim of this study is to evaluate the perceptions about the local brand as a way to attract entrepreneurs, tourists and business development in the wine area Pietroasele, Buzau, Romania based on the following specific research objectives:

1. Knowledge of the role of the local brand in the management of local businesses and authorities.

2. Monitoring the application of mechanisms used by specialists to develop local branding, including collaboration with local partners.

3. Evaluation of the perspectives arising from the development of the analyse brand.

Keywords: Pietroasele, label wine, local marketing, branding

JEL Classification: $A 11 ; A 14 ; B 21$. 


\section{Introduction}

The branding concept has advanced more and more as a way of application from shopping malls, shopping malls, to areas, regions and states. Practice has shown that the implementation of a brand requires multidisciplinarity from specialists. For example, when we talk about marking products and services in parallel, it appears with the marking of producers, areas of origin [7],[8], local tourism [9], [10], of cities in the vicinity of areas [1], [2].

In recent years, branding as a discipline has evolved in terms of communication and implementation, highlighted by an evolution of knowledge at different levels [13], [14] local authorities, tourism organizations and media.

Local marketing has evolved from what it means to the reputation of the area, to a strategic vision and a focused promotion of products [15], [16] [17]. Moreover, as the concept of "entrepreneurship" evolved into a business approach, branding emerged in terms of business perceptions and attitudes [4], based on people's experience of places [18], regardless of whether they referred to an entire city or smaller areas [19].

Recently, branding experts claim that there are parallels and gaps between brand management and site management. [20] [18].

These have been studied in his previous research [21] [22] which states that this multidisciplinarity can be developed by establishing public-private partnerships and by a more balanced approach to site management [23].

This study also seeks research [24] on the management of a future tourist destination, in terms of the links between local branding and regional planning for a local brand building, with a focus on professionals involved in managing partnerships.

The starting point of this study is the connections of recent works (Fig. 1) that follow the link between stakeholder theory and place branding [25] for creating destination brands using qualitative methods for strategy of target branding, in creating a target image and a branding model.

Fig.1.General framework of approaches

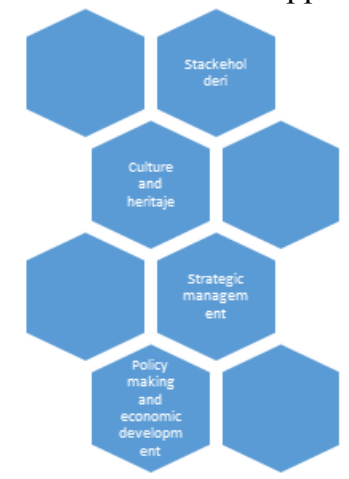

Source: authors' processing [6]

\section{Methods}

The concept of branding has been defined over time, starting from knowing the identity of the product to the applicability at the level of techniques for marking the areas of origin of products. including regions and cities.

Another analysis of the branding literature of area marketing over a period of 20 years found that there was a lack of consensus on what needles represent the potential of the place and the brand of the products [9] . effects and on other categories, services and other places. In the evolution of brand thinking, applicability at the level of products, the 
multitude of their uses in the area has created a consensus in terms of branding the area (Hankinson, 2004).

One of the current interpretations is his, which suggests that local branding pursues a process in developing and managing the perceptions of the target audience on specific places in order to influence their behaviors and ultimately contributing to the development and sustainability of the area. Other researchers have argued that for marketing and branding strategies to be successful, sites must be actively managed to meet the multidimensional interests of different stakeholders [9].

\subsection{Site management}

The increase of marketing activity and implicitly of local branding, shows that areas, regions should be managed as actively [1] as products or goods [5], [8] able to attract market segments with specific expectations. Some researchers [10] have argued that consumption patterns for tourist destinations (where events and promotions specifically differ from one area to another have more stable and sustainable brands.

Historical and cultural localities have advantages because they are destinations that attract tourists due to their attributes. The management of these locations involves a coordination of all public-private partners, for the valorization of resources, skills of specialists, entrepreneurs [11] The same phenomenon occurs on city centers as shopping destinations.

In the UK and other areas [17] [20]over time, a number of management typologies have emerged that are based on companies in a selected area that agree to pay an additional fee aimed at improving places [6].

An increasing number of researchers [9], [16]) recognize the issue of branding the area is essential to capitalize on the tangible and intangible characteristics of places in order. to attract investment, tourism and potential new residents [20]; suggests that branding is the "starting point" for place marketing.

Similarly, the importance of strategic marketing plans in an effective local practice, driven by local marketing, is emphasized by [25] who argued that this concept in Spain has evolved from a simple promotional tool to a complex strategic urban revitalization for internal investigations, through effective marketing and branding in the city, like the "Guggenheim effect" [10].

Other researchers such as (Nation Branding: Toward an Agenda for Critical Research, 2011) have argued for the need to integrate place branding techniques into local policy formulation and management, emphasizing that researchers in Germany place greater emphasis on branding strategies. of places than the British, who often tended to focus on aspects of the retail competitiveness of city centers.

There also seems to be a greater consensus on this, on what stakeholders are and especially local people [3] should be actively involved in business development [10] and area management interventions [12], [21], even if their degree of involvement remains contested issues [16]

A public-private partnership brings together a wide range of key interests, and the emergence of a professional body for the sector in the form of a research and site management institution will be a key catalyst in this process and has become essential in reducing the gap between management and site marketing [17].

2.2. Sampling and profile of interviewees. During March-September, 10 interviews were conducted with local business representatives, researchers, farmers from the Buzau area, Romania, presented in table 1. 
Table 1. Interviewee profile

\begin{tabular}{|c|c|c|c|c|}
\hline No.crt. & $\begin{array}{l}\text { Level of } \\
\text { responsibility }\end{array}$ & Current employer & $\begin{array}{l}\text { Industry } \\
\text { experience } \\
\text { (years) }\end{array}$ & Area served \\
\hline 1 & Researcher, Pietroasele & $\begin{array}{l}\text { Branding and event } \\
\text { management consulting }\end{array}$ & 31 & Buzău, Romania \\
\hline 2 & Manager Pietroasele & $\begin{array}{l}\text { Branding and urban } \\
\text { management consulting }\end{array}$ & 38 & Buzău, Romania \\
\hline 3 & Farmer CEO & Engineer & 18 & Buzău, Romania \\
\hline 4 & Economic Director & Local Authority & 18 & Buzău, Romania \\
\hline 5 & Employer & Engineer, Pietroasele & 11 & Buzău, Romania \\
\hline 6 & Senior manager & Local Authority & 10 & Buzău, Romania \\
\hline 7 & Director & $\begin{array}{l}\text { Director of a consulting } \\
\text { company }\end{array}$ & 5 & Buzău, Romania \\
\hline 8 & Employer & Young graduate & 2 & Buzău, Romania \\
\hline 9 & Director & Processing Company & 8 & Buzău, Romania \\
\hline 10 & Director & $\begin{array}{l}\text { Director of a consulting } \\
\text { company }\end{array}$ & 4 & Buzău, Romania \\
\hline
\end{tabular}

\subsection{Interview procedures and questions}

The research focused on making interpretations in the application and implementing Pietroasele brand images by local professionals in the Buzău area, Pietroasele. This was done using semi-structured interviews, encouraging open-ended responses and allowing researchers to respond and clarify as needed.

The interviewees were selected so as to provide a comprehensive (though not generalizable) characterization of the local branding process. The interviewees were initially approached by e-mail, which briefly presented the objectives of the study and invited them to participate. Respondents who agreed to participate in the first then an email for the second time and sent an informed consent form, which presented the research objectives and offered to the anonymous respondents in exchange for their participation.

While the interviews were based on a set of open-ended questions, we summarized in Table 2 the initial interview topics for the three research questions, and Table 3 presents the final set of interview questions. 
Table 2. Research objectives Discussion topics

\begin{tabular}{|l|l|}
\hline $\begin{array}{l}\text { 1.To determine the role and importance of } \\
\text { local branding in the vision of the local } \\
\text { community }\end{array}$ & $\begin{array}{l}\text { - Knowing the importance of the local brand } \\
\text { Local brand identities. } \\
\text { - The level of application of the brand regardless } \\
\text { of whether it is strategic or operational. }\end{array}$ \\
\hline $\begin{array}{l}\text { 2. To examine the extent to which the } \\
\text { application of place branding is effective in } \\
\text { the development and management of places }\end{array}$ & $\begin{array}{l}\text {-Methods to increase effectiveness. } \\
\text { - The impact of public policies on ongoing } \\
\text { branding activities. }\end{array}$ \\
\hline $\begin{array}{l}\text { 3. To evaluate the potential ways for the } \\
\text { future of place branding in creating the place. }\end{array}$ & $\begin{array}{l}\text { The future role of place branding. } \\
\text { - the local brand will be integrated in the policies } \\
\text { of the local authorities } \\
\text { Responsibility in making the branding of the } \\
\text { place. }\end{array}$ \\
\hline
\end{tabular}

Table 3. Interview questions.

The role and importance of the brand at stakeholder level (research objective 1)

- What do you think is the branding of the place in your opinion?

- Do you consider place branding strategic to develop and manage your place?

- What are strategic actions and programs in the authorities' vision of the local brand?

- Do you think that branding activities should be carried out by consultants, rather than using in-house expertise?

Brand application model in business development (research objective 2)

- To what extent do you think the Pietroasele brand has been effective so far?

- How effective do you think the internet has been in launching your brand?

- What are the effects of political discontinuities on ongoing branding activities and how can managers mitigate these effects?

Assessing the future (research objective 3

- What difference do you think makes the place mark for a place management and place development project (in terms of place / people benefits?

- What role do you think place branding will play in the management and development of places in the future?

- How well is this system embedded in local politics?

- How do you see this as functional or strategic for your site?

The results of the interviews were analysed as follows:

Both inductive and deductive approaches were combined, with researchers generating significance from the data collected. Using a bottom-up approach, all interviews were verified. A revision was carried out to gather the codes and reclassify the quotations if necessary, in order to provide a more coherent and complete framework. Code descriptions have also been developed to ensure consistency. The main themes were compared and linked between the three themes to render a complete picture with final common themes for further analysis (Fig.3).

\section{Results and discussions}

\section{Practitioners' perceptions of the local brand}

Study participants revealed a rather heterogeneous set of interpretations of the place brand as a concept, as well as its role in place management. For example, the managers of 
the most representative businesses tended to adopt a strategic approach to branding placement and even formed subregional partnerships; while an operational perspective on the local brand seemed to predominate elsewhere.

Despite these differences and the potential north-south division, respondents were unanimous in their support for the role of partnerships in unifying local stakeholders as part of the local branding process.

When asked to describe the local brand, respondents referred to issues of place identity $(n=8)$, competitiveness $(n=6)$, differentiation $(n=6)$, attractiveness $(n=4)$.

\section{Place branding culture and heritage}

The majority of participants $n=7$ agreed that culture and heritage should play a key and central role in marking places. Regarding the brand's potential on local development, its interference with adjacent places was mentioned as a way to attract investment and tourism in their area.

Regarding the potential of local branding in creating community responsibility, to contribute to social cohesion and to increase the attachment of the inhabitants [22] it is very confusing. interview participants pointed out that branding processes are often confused with a beautiful logo and slogan for the area. Moreover, some interviewees claimed that the managers of the local authorities understand the brand notion of the area completely differently. We detail the answers given by them in relation to the stakeholders regarding the Pietroasele brand.

The importance of the management of the area was highlighted unanimously by the participants, as follows:

- Pietroasele wine park as a local brand (label) could offer exposure to producers, participants in the value chain and would serve as a reference point for visitors who want accommodation or new travel experiences.

- Local events have the ability to stimulate cultural and visual consumption among residents and visitors and to shape the distinctive image of the host commune / locality. This is the main reason why larger cities have begun to see events as a branding tool. Ex. Tamaioasa Festival

- The initiative „Pietrosele Wine Park could promote sustainable mobility and slow tourism in all parks in Buzau County, encouraging visitors to discover the picturesque beauty of Dealul Mare vineyard in an ecological way, using public transport, innovatively by making special cars that to take a tour of the Wine Road.

- Pietroasele, in collaboration with the Romanian Railways, could create a series of tourist products centered around objectives to stimulate the local economy by directing visitors to this region.

- Pietroasele supports green energy in order to promote renewable energies and energy efficiency, involving energy suppliers, construction companies, educational institutions, municipalities and the management of the wine park.

- The Pietroasa Istrita research station considers that effective research and development is vital to remain a competitive unit in the wine industry and the tourism industry. Since 1893, the resort has research and development, human resources consists of 65 people engaged in research and development. Wine sales increased in 2020 by $7.57 \%$ compared to 2019 .

- Pietroasele invests in the modernization of technologies and infrastructure by accessing projects with national and international funds and a substantial part of the resources in research and development activities. The Pietroasele research resort has a unique mission of 
127 years in the service of Romanian viticulture and a mission to lead in the future the development through innovation of regional and national viticulture and vinification; as a subsidiary of university, Pietroasele Resort is a global leader in open innovation for human mobility systems of both the physical and digital world, giving rise to the development of local regional and national enterprises

\section{Conclusions}

Building resilient place marks is a long-term commitment [4] that must adapt over time to the evolution of places as living entities [5] and capitalize on the tangible and intangible features of the place [19].

[16] argue that these are fundamental questions that remain unanswered when it comes to strategic branding planning and whether there is a strategic orientation or tactical practice.

In addition, the main argument of confusing branding related to industry practitioners in the regions presented above seems to find congruence with [8]Ashworth and Kavaratzis, who convincingly confirms that "the non-geographical thinking of many commentators and practitioners working in the field has led to confusion in regarding the social and spatial implications of the place brand".

As pointed out at the beginning of article, local authorities, which are affected by their declining budgets and which could lead to regional disparities, can reduce these phenomena by increasing their focus on specific local marketing and activities. promotion without a broader branding strategy.

The results of this study show that place branding remains a rather heterogeneous concept among practitioners in the management of the Pietroasele Buzau area, Romania, a wide variety of interpretations of this concept resulting from the responses of participants in this study.

The parallels mentioned by some interview respondents between place branding and corporate branding, subject to a somewhat contested analogy between product and place [18], that "places have images just as products and corporations have images and that places they depend to a similar extent on the power and attraction of these images for their progress and prosperity.

Based on the above premise, it was not surprising to find that most of the interviewees seemed to be dependent on consultants in terms of support for the site branding process. Branding was often limited to aspects of logo design. Despite this, there was unanimous agreement among local government professionals that local branding should be fundamental about creating the places people want to be, which reflects the conceptual framework of the study insofar as local experiences are closely related to the images of the place, as well as a sense of uniqueness and authenticity.

\section{References:}

1. Cucari, N.; Mugova, S. Corporate sustainability in the tourism sector: Is «m-Integrated Reporting $m$ » an appropriate strategy? In Proceedings of the Proceedings of the 5th International Conference on Management Leadership and Governance, ICMLG 2017; 2017.

2. Garrod, B.; Fyall, A. Beyond the rhetoric of sustainable tourism? Tour. Manag. 1998, doi:10.1016/S0261-5177(98)00013-2.

3. Sharpley, R. Tourism development and the environment: Beyond sustainability?; 2009; ISBN 9781849770255.

4. Hall, T.; Hubbard, P. The entrepreneurial city: New urban politics, new urban geographies? Prog. Hum. Geogr. 1996, doi:10.1177/030913259602000201. 
5. Langemeyer, J.; Baró, F.; Roebeling, P.; Gómez-Baggethun, E. Contrasting values of cultural ecosystem services in urban areas: The case of park Montjuïc in Barcelona. Ecosyst. Serv. 2015, doi:10.1016/j.ecoser.2014.11.016.

6. Cassia, F.; Magno, F. Business-to-business branding: A review and assessment of the impact of non-attribute-based brand beliefs on buyer's attitudinal loyalty. Can. J. Adm. Sci. 2012, doi:10.1002/CJAS.235.

7. Parkerson, B.; Saunders, J. City branding: Can goods and services branding models be used to brand cities? Place Brand. 2005, doi:10.1057/palgrave.pb.5990026.

8. Pike, S.; Pike, S. Destination image. In Destination MarketingDestination Marketing; 2020.

9. Avraham, E.; Ketter, E. Media strategies for marketing places in crisis: Improving the image of cities, countries and tourist destinations; 2012; ISBN 9780080557076.

10. Dinnie, K. Destination branding for small cities: The essentials for successful place branding. $J$. Brand Manag. 2009, doi:10.1057/bm.2008.38.

11. Kokosalakis, C.; Bagnall, G.; Selby, M.; Burns, S. Place image and urban regeneration in Liverpool. Int. J. Consum. Stud. 2006, doi:10.1111/j.1470-6431.2006.00520.x.

12. Tallon, P.P. Corporate governance of big data: Perspectives on value, risk, and cost. Computer (Long. Beach. Calif). 2013, doi:10.1109/MC.2013.155.

13. Braun, E.; Eshuis, J.; Klijn, E.H. The effectiveness of place brand communication. Cities 2014, doi:10.1016/j.cities.2014.05.007.

14. Medway, D.; Swanson, K.; Neirotti, L.D.; Pasquinelli, C.; Zenker, S. Place branding: Are we wasting our time? Report of an AMA special session. J. Place Manag. Dev. 2015, doi:10.1108/JPMD-12-2014-0028.

15. Ashworth, G.; Voogd, H. Marketing and place promotion. In Place Promotion: The Use of Publicity and Marketing to Sell Towns and Regions; 1994.

16. Gnoth, J. Leveraging export brands through a tourism destination brand. J. Brand Manag. 2002, doi:10.1057/palgrave.bm.2540077.

17. Eisenschitz, A. Neo-liberalism and the future of place marketing. Place Brand. Public Dipl. 2010, doi:10.1057/pb.2010.12.

18. Mahmoudzadeh, S.M.; Samiei Nasr, M.; Hashemi, M. A survey on factors influencing city branding. Manag. Sci. Lett. 2014, doi:10.5267/j.msl.2014.9.001.

19. Steel, M.; Symes, M. The privatisation of public space? The American experience of business improvement districts and their relationship to local governance. Local Gov. Stud. 2005, doi:10.1080/03003930500095152.

20. M., B.; K., T.; B., V.G. The selective nature of place branding and the layering of spatial identities. J. Place Manag. Dev. 2011.

21. Stubbs, B.; Warnaby, G.; Medway, D. Marketing at the public/private sector interface; town centre management schemes in the south of England. Cities 2002, doi:10.1016/S02642751(02)00040-9.

22. Warnaby, G.; Bennison, D.; Davies, B.J. Marketing communications in planned shopping centres: Evidence from the UK. Int. J. Retail Distrib. Manag. 2005, doi:10.1108/09590550510634620.

23. Riviezzo, A. Acquisitions in knowledge-intensive industries: Exploring the distinctive characteristics of the effective acquirer. Manag. Res. Rev. 2013, doi:10.1108/01409171311292270.

24. Zavattaro, S.M.; Daspit, J.J.; Adams, F.G. Assessing managerial methods for evaluating place brand equity: A qualitative investigation. Tour. Manag. 2015, doi:10.1016/j.tourman.2014.08.018.

25. Tasci, A.D.A.; Gartner, W.C. A practical framework for destination branding. Bridg. Tour. Theory Pract. 2009, doi:10.1108/S2042-1443(2009)0000001013. 